\title{
Habitability, a Basic Premise for Home Design and Its Impact on the Curricula of Architecture Schools
}

\author{
Gildardo Herrera-Sánchez, Victor Manuel Garcia-Izaguirre* \\ Faculty of Architecture Design and Urbanism, Autonomous University of Tamaulipas, México
}

Received June 9, 2020; Revised August 12, 2020; Accepted August 25, 2020

\section{Cite This Paper in the following Citation Styles}

(a): [1] Gildardo Herrera-Sánchez, Victor Manuel Garcia-Izaguirre, "Habitability, a Basic Premise for Home Design and Its Impact on the Curricula of Architecture Schools, "Civil Engineering and Architecture, Vol. 8, No. 5, pp. 950 - 962, 2020. DOI: 10.13189/cea.2020.080522.

(b): Gildardo Herrera-Sánchez, Victor Manuel Garcia-Izaguirre (2020). Habitability, a Basic Premise for Home Design and Its Impact on the Curricula of Architecture Schools. Civil Engineering and Architecture, 8(5), 950 - 962. DOI: 10.13189/cea.2020.080522.

Copyright $\mathrm{O} 2020$ by authors, all rights reserved. Authors agree that this article remains permanently open access under the terms of the Creative Commons Attribution License 4.0 International License

\begin{abstract}
The demand for housing in Mexico increases year after year, in which the architects have actively participated in its design and production. This study aims to investigate whether the architectural production generated by professionals graduated from the different three study plans of the Faculty of Architecture, Design and Urbanism of the Autonomous University of Tamaulipas has had a greater impact on the resolution of the habitability of the houses. To resolve the above issues, we apply two data collection instruments that would measure such a situation to a representative sample of the three study plans. The results obtained show that regardless of the study plan, all the graduates demonstrated to have, in addition to knowledge, capacities and skills for the design of comfortable homes, the ability to solve the aspects of habitability in the home, which breaks the paradigm that previous plans were better than current ones. This also implies the recognition of the academic process that is followed in public higher education institutions versus private schools, which is not affected by this condition; as well as the fact that the new technologies that are currently used in all disciplines have not detracted from the abilities that an architect must have.
\end{abstract}

Keywords Architect Training, Habitability of the Houses, Housing Design, Housing Production, Public Higher Education Institutions

\section{Introduction}

Considering the construction of houses is a process as complex as human nature and at the same time a vital necessity and a costly good for all the inhabitants of this planet, the present investigation has raised the fact of identifying cognitive capacities, which occurs specifically in the training of Mexican architects.

Various studies were carried out regarding housing in Mexico (Canales [1]; Cabrera [2]); Bazant [3]) have exposed the various problems facing urban areas. One of them is the phenomenon of rural migration, which has generated a population concentration in the cities. This has demanded the creation of housing, mainly in housing complexes of social interest, several of which do not meet the minimum conditions of habitability. This situation occurs when they are located in zones unsuitable to inhabit, are occupied, divided into lots and subdivided; an issue that has been stimulated in part by the low cost of land peripheral to cities, which are incorporated into them without good urban planning.

In this sense, the Housing Law, issued by the Government of Mexico in June 2006, has no clear indications regarding the parameters that should be considered to meet the habitability condition, specifying in Article 2 that "A home worthy will be considered to be one that complies... with habitable and auxiliary spaces..."; an issue that does not stipulate parameters to provide an adequate solution to housing needs. 
Under the previously described, this research was proposed, with the intention to investigate whether the architectural production of homes in the southern area of the state of Tamaulipas, carried out mainly by graduates of the Faculty of Architecture, Design and Urbanism (FADU) of the Autonomous University de Tamaulipas (UAT), in the 10 years prior to 2015, considered its design, the habitability factor. This knowledge should have been acquired in the architect's academic and professional training, even when the minimum conditions that must be fulfilled are not established under Mexican regulations, but they have been raised as necessary knowledge in Architecture schools.

Additionally, another purpose for carrying out this study was derived from the fact that in the southern metropolitan area of Tamaulipas, Mexico, there is a considerable percentage of low-income housing that was modified in its original designs. There is an interest to know if these were designed by the graduates of the FADU-UAT, or are derived from the social programs and social production of housing of the Government of Mexico.

In this sense, the main problem posed is that of detecting whether the graduates of the FADU-UAT, under the academic-professional training received, in any one of the three study plans, have marked differences in knowledge, skills or abilities, to efficiently solve the demand for housing production with adequate habitability conditions, specifically in the aspects of physical and psychological comfort, as well as the aesthetic value, essential in the design of habitable spaces.

Therefore, it was established as a general objective of the research: "Evaluate the three curricula, taught at the FADU from its foundation until the moment of conducting this research, for the discipline of Architecture, in order to compare the architectural work of the graduates of each plan in the architectural design of homes within the metropolitan area of southern Tamaulipas."

From this the following study variables were established:

- Independent variable: FADU-UAT study plans (Plan

71, Mission XXI and Millenium III).

- Dependent variable: Architectural production of the graduates of each plan in the generation of housing.

Two data collection instruments were designed to evaluate and analyze both variables, including abilities, tools and knowledge of graduates in this profession, in addition to analyzing their architectural production.

For the above, a study with a quantitative approach with a simple correlation analysis was considered pertinent, to check the hypothesis raised that "The different study plans for the professional training of architecture students at the FADU of the UAT, have marked differences in the production of their professional graduates, evidenced mainly in the area of housing".

This allowed us to answer the questions that this investigation raised, which are described in more detail in the subsequent sections.

\section{Background}

The habitability is to architecture as reasoning is to man, and this thought that is inextricably connected has allowed that the human being has always been able to provide a comfortable home according to his needs, adapting materials and constructive systems, in the environment in which it has had to develop, for its protection and the satisfaction of its needs, both physical, biological and psychological. This is what is now known as architecture. (Barrios [4]; Vitrubio [5])

However, within the context of architecture, there is a conceptual indeterminacy, which designates at least three different things:

1. Firstly, to the discipline that contains the knowledge, tools, concepts, and skills of the architects' training.

2. Secondly, to the intellectual activity through which architectural buildings or spaces are designed or projected.

3. Thirdly, to the products of this intellectual activity, mainly to identify it in a style or genre.

To clear up this confusion, Barrios [4] proposes that: "(...) It is considered that the term is the expression of the idea, the term architecture is used, regardless of the three different concepts, designating the discipline dedicated to the training of architects as architecture; as an architectural design to the intellectual process that generates habitable spaces for man; while the architectural work would be the materialized product of the architectural design".

Considering the above, the architectural phenomenon consists of the discipline that provides the knowledge, skills and abilities for the architectural design process it produces, the buildings, or architectural spaces.

Thus, the architects must then build any construction considering habitability as the set of conditions of the architectural space that meet the needs of the human being, for the best performance of their activities. (Roux-Gutiérrez, R., Espuna-Mujica, A. \& García-Izaguirre, V., [6])

According to the National Housing Commission, (acronym in spanish CONAVI), [7] between 700,000 and one million homes must be financed and built each year in Mexico.

In this context, and according to constitutional article 4, the objective of public policy for the Mexican government is to make feasible for anyone, the possibility of buying, building, remodeling or renting a home according to their economic ability and preferences.

In that sense, it is noteworthy that the House Research and Documentation Center, (acronym in spanish CIDOC), [8], has determined that the demand for housing by type of credit was $56.4 \%$ for acquired homes, $29.5 \%$ for 
improvement and $14.1 \%$ for self-built housing; highlighting that the latter compared to 2012 decreased by almost $31 \%$. This indicates an increase in the professional practice of architects for the design and construction of homes.

But for this same reason, and even if this type of building is so required, housing itself is as complex as human nature, which according to Barrios [9] is a vital necessity and an expensive asset, of which a large part of society does not have the necessary financial resources to access it.

In general, in the houses built in the metropolitan area of southern Tamaulipas, formed by the municipalities of Tampico, Madero, and Altamira, there is a high probability that the architects who graduated from Higher Education Institutions (HEI) have participated in one way or another, and produced by the most prominent developers in the region.

However, these buildings have had to adapt to find their habitability, either through extensions or adaptations, reorganizing and reconfirming the spaces, shapes, and textures.

The latter contravenes what in theory should be the architectural solutions, which, depending on the needs and activities of the future user, should be generated appropriately for them and not cause the user to adapt to a proposal of architectural space that is not projected according to their actual needs for various reasons. No matter what these reasons are, the problem is that many of these architectural solutions lack the necessary habitability conditions.

Studies carried out by other HEI report that at least 55\% of its graduates work mainly in the construction industry and in second place is $13 \%$ working in government services. Among the activities the graduates carry out, the management and coordination of projects stand out with $26 \%$, followed by supervision with $18 \%$. (UAM, [10])

This implies that a vast majority of these professionals have been dedicated for the construction of homes at all socioeconomic levels, ranging from those of social interest to those of a residential nature. According to Espuna, Elías, Montalvo, and Rosas [11], the most significant architectural production is that of housing, where the design concept is applied from the first workshops dedicated to learning architecture.

The results obtained would imply, according to the CIDOC [8] that the HEI must take these considerations into account in order to implement and adapt them into the formative processes of the architects, so that they graduate with an integrated understanding and apply it according to the needs of the society. It would have to change in the coming years in terms of the type of housing that is built, who builds it and where it is built.

Until 2015, the time limit established for the study, the educational program of the Architect's career at FADU-UAT, has had graduates from three study plans (Table 1), who have received their names according to the administration that established them or the requirements at the time when they were instituted.

Table 1. General characteristics of the FADU curricula

\begin{tabular}{|c|c|c|c|c|}
\hline $\begin{array}{c}\text { Curriculum } \\
\text { (P.E.) }\end{array}$ & $\begin{array}{c}\text { Start of } \\
\text { P.E. }\end{array}$ & $\begin{array}{c}\text { 1st } \\
\text { Generation } \\
\text { graduated }\end{array}$ & $\begin{array}{c}\text { End of } \\
\text { P.E. }\end{array}$ & $\begin{array}{c}\text { Last } \\
\text { generation } \\
\text { that } \\
\text { graduated }\end{array}$ \\
\hline P-71 & 1971 & 1976 & 1999 & 2004 \\
\hline P-MXXI & 2000 & 2005 & 2005 & 2010 \\
\hline P-MIII & 2006 & 2011 & 2014 & 2019 \\
\hline
\end{tabular}

Source: Prepared by the researchers in 2015

Specifically, in September 1971, the current FADU was founded, which begins with the career of Architects, whose teaching staff emerged from the College of Architects of the metropolitan area of southern Tamaulipas.

This first curriculum of FADU, Plan 71 (P-71), was strictly based on that of the UNAM National School of Architecture; ENA-UNAM created in 1967.

Issues to highlight in this plan of study are:

- The curriculum consisted of ten semesters, which had a total of 59 subjects. Its central axis of knowledge with 10 subjects was that of Architectural projects, of which housing projects were developed in two subjects, with a marked tendency towards the building.

- The graduate profile considered that architecture student should be prepared to lead men and companies.

- The curriculum contributed to society, the resolution of urban problems, or in a particular way those of residential spaces.

The second curriculum implemented at FADU-UAT, called Mission XXI (P-MXXI), was taught from January 2000 under a model whose professional training is organized by: “(...) Training centers and within the framework of the new Flexible Curriculum model that introduced the following changes: New ways of transiting through the Study Plans, new forms of teacher participation, new ways of organizing research and linking, new ways of organization in the Faculties and Academic Units, new school management systems and, updating of university legislation (Filizola, [12])."

Highlights of this plan of study:

- The curriculum was made up of ten semesters, which had a total of 50 subjects, its central axis being Architectural Projects with 10 subjects, of which housing projects were developed in three subjects. It is worth noting the creation of the Digital Systems nucleus with five subjects, which did not exist in the previous plan.

- Total Credits to be taken 399, of which 288 credits are compulsory of named subjects; co-curricular, disciplinary and professionalizing courses and 111 credits of elective or optional subjects. 
- The graduate profile sought to train individuals with an innovative technical and humanistic vision, sensitive to the requirements of their social context and trained to contribute to the improvement of the habitable spaces of mankind, through the adequate solution of spatial problems and the selection of the materials appropriate to the specific environment.

The third curriculum was named, Millenium III (P-MIII), and began in 2006 .

The characteristics of this plan of study are:

- The curriculum was made up of ten semesters, with a total of 62 subjects, with its central axis of knowledge including 10 subjects of architectural projects, four of which were housing projects.

- Total Credits to be taken 368 , of which 40 credits corresponded to the optional subjects. The plan was organized in four training nuclei: University Basic that operates as a common core for the careers that are taught at the UAT and FADU and that respond to the specific requirements of a program; Professionalism, this is compulsory; Disciplinary, through which the understanding of Professional subjects is facilitated; Electives whose intention is the consolidation of a specialty or training accentuation, which can be chosen gradually through the various periods of the degree.

- The graduate profile establishes a professional capable of performing in the sciences and disciplines of the design, planning, execution, and supervision of different types of architectural projects that meet the habitability needs of human beings, from the most concrete biological needs to the most abstract ethical and aesthetic. These are typical of the integral development of the potential of the individual and the communities.

- The study plan enables professional skills to be developed through the acquisition and organization of knowledge, the development of abilities, skills, attitudes and values based on real problems, integrating the contents of the different areas of knowledge from an interdisciplinary perspective.

\section{Methodology}

According to García [13], educational research has the ultimate objective of helping to explain and understand the phenomena that have occurred in the scholastic world in general and in the didactic act in particular.

Therefore, based on the stated objective, it was necessary to establish a methodological process, in order to define the spatial characteristics inherent in the conception of architectural design, reviewing the cognitive aspects and psychomotor skills that each curriculum contained.

According to Nadal [14], the evaluation consists in determining the extent to which the proposed objectives have been achieved, and whether the most appropriate methods have been used to achieve it.

In this sense, this research was carried out in two different and complementary phases (figure 1), which respond to the idea that, to evaluate the study plans taught for the Bachelor of Architecture at FADU since its foundation and the production of architectural graduates, they should include the following:

I. A descriptive analysis of the three curricula, which allows finding the most significant coincidences or divergences of the professional training of the architecture graduate.

II. Design and apply a data collection instrument to:

a) Evaluate the curriculum, specifically about the graduate profile, areas of knowledge, skills, abilities, tools, and knowledge and skills acquired by graduates through the thematic contents of the training subjects.

b) Analyze the architectural production of graduates of each plan in the generation of homes, according to the parameters of habitability: Physical dimensions; Spatial syntax; Physical comfort and spiritual comfort. (Barrios, [9]). 


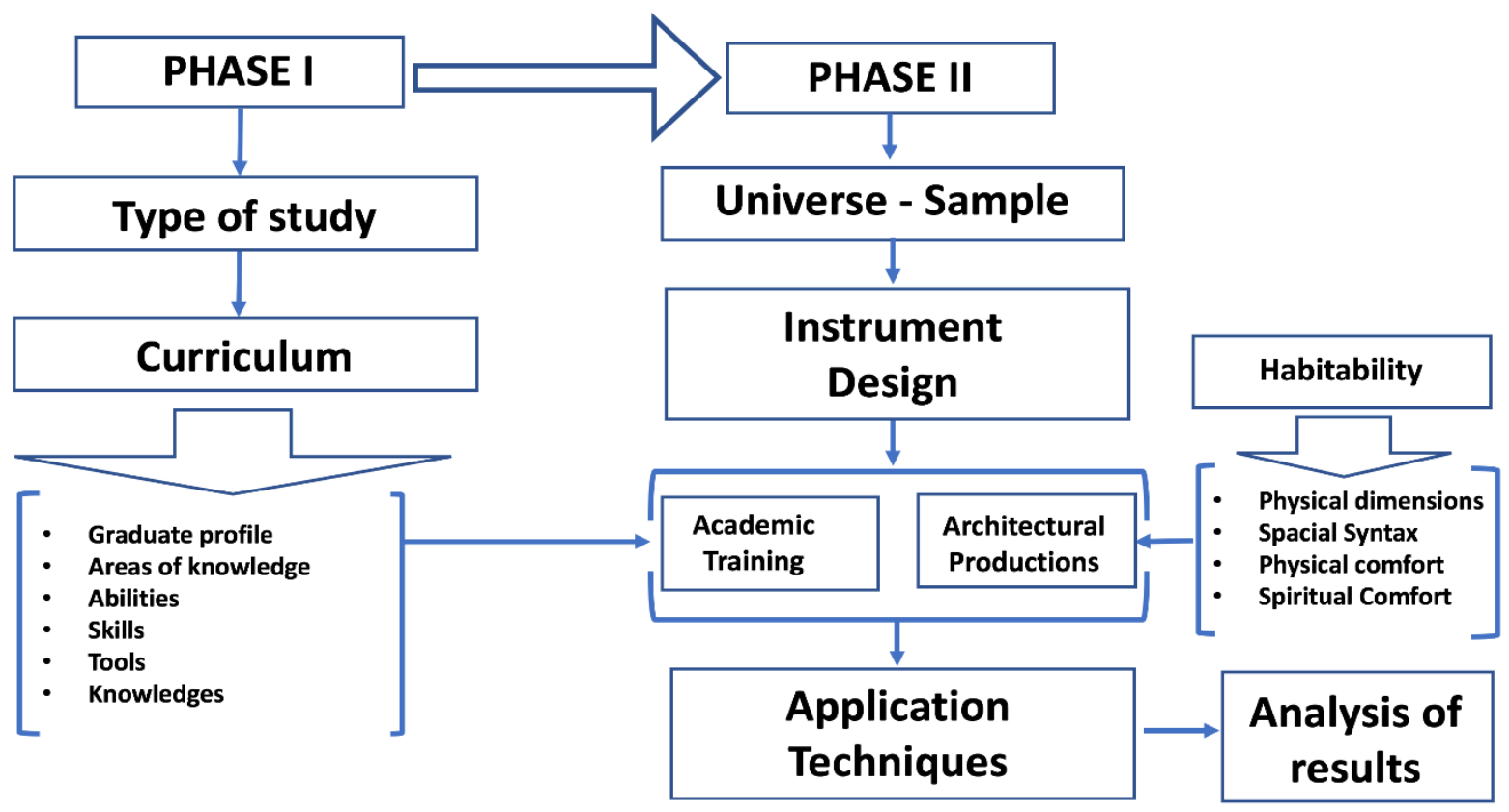

Source: Prepared by the researchers (2015).

Figure 1. Methodological scheme applied to the project.

These two different phases are interconnected, in order to obtain the results of the investigation, with which the study variables could be measured.

Regarding these two phases, it was considered pertinent that the study had a quantitative approach, since per Hernández, Fernández - Collado, and Baptista [15], the research will use data collection to test a hypothesis based on the numerical measurement and statistical analysis, to establish patterns of behavior and test theories.

In the case of phase I, it was also considered to be non-experimental, since there is no control over the independent variables, corresponding to the three different study plans, because the events have already occurred. The variation of the independent variables will be achieved not by direct manipulation but through the selection of the analysis units in which the studied variable has a presence.

Additionally, a descriptive transactional design was applied, which allowed collecting data from each plan in a single moment, in order to describe the independent variable, in order to analyze its incidence and interrelation with the dependent variable.

To finally apply a descriptive study, that seeks to specify the important properties of people, groups, communities or any other phenomenon that is subjected to analysis that, according to Hernández, et al. [15] seeks to specify properties, characteristics and important features of any phenomenon that is analyzed. It is intended to describe the why of a phenomenon and under what conditions it occurs, or why two or more variables are related.

Regarding phase II, the universe of this research consisted of all the graduates of the different study plans of the FADU - UAT architectural education program. Considering the time limit established until December
2015, the universe was 2896 graduates, according to data provided by the FADU-UAT School Department. which have been categorized by study plan (table 2), in which the percentage that represented for each of the total graduates was determined.

Table 2. Universe - shows graduates of Architecture FADU-UAT

\begin{tabular}{|c|c|c|c|}
\hline $\begin{array}{c}\text { Curriculum } \\
\text { (P.E.) }\end{array}$ & $\begin{array}{c}\text { Total } \\
\text { graduates }\end{array}$ & \% Graduates & Sample \\
\hline P-71 & 2201 & $75 \%$ & 186 \\
\hline P-MXXI & 333 & $11 \%$ & 27 \\
\hline P-MIII & 362 & $14 \%$ & 35 \\
\hline Total & 2896 & $100 \%$ & 248 \\
\hline
\end{tabular}

Source: Prepared by the researchers (2015).

The sample size was determined under stratified sampling based on the percentage corresponding to each plan, considering $90 \%$ reliability, $50 \%$ dispersion and $5 \%$ margin of error.

Finally, the elements of the sample were selected in a non-probabilistic way, taking into consideration the following inclusion and exclusion criteria.

Inclusion criteria:

Graduates must:

- Be entitled or be in the process of qualification.

- Be in the metropolitan area of southern Tamaulipas.

- Have designed or built at least one dwelling that is currently inhabited.

- Have designed or built the house in the metropolitan area of southern Tamaulipas.

- Have designed or built the home within the first five years after discharge. 
Exclusion criteria:

- Those who did not meet the inclusion criteria.

- Those who do not want to participate in the study.

Phase II also involved designing and applying two data collection instruments:

a) The first to evaluate the curriculum, specifically regarding the graduate profile, areas of knowledge, abilities, skills, tools, and the knowledge and skills acquired by graduates through the thematic contents of the training subjects.

b) While the second would allow comparing the architectural production of graduates of each study plan, in the generation of housing, considering exclusively the following parameters of habitability: Physical dimensions; Special syntax; Physical comfort and spiritual comfort.

Regarding the first instrument, referring to the graduate profile, the three study plans were analyzed and the coinciding factors were sought in order to homogenize and be able to have a relevant comparison between them.

While, to measure the knowledge and skills acquired by graduates through the thematic content of the training subjects, the instrument applied to the country's professionals has been taken as the base model, to design the General Examination for Graduate Studies in Architecture (EGEL-ARQUI) developed by the National Evaluation Center for Higher Education, AC (CENEVAL, [16]).

Depending on the disposition and choice of the sample element, two formats and ways were used to deliver it:

I. Format printed and answered in the presence or nearness of the researcher.

II. Digital format sent via email and answered and returned by the same means to the researcher.

As expressed by Manzano and Zamora [17] in many disciplines related to the social sciences, it is usual to try to measure highly complex phenomena such as intelligence, motivation, efficiency, perception, among others, based on perceptions, opinions, indicators and specific or approximate variables, which are called latent variables.
In the words of Monroy, Vidal and Saade [18] in the social sciences, a large part of the variables of interest in the discipline cannot be observed directly, so the latent variables and their value depend on the variables observed or manifested.

In order to solve the data analysis, the simple correlation statistical model (1) was used to measure the intensity of the linear relationship between the two study variables.

$$
r=\frac{S C(x y)}{\sqrt{S C(x) S C(y)}} \cdots
$$

For the purposes of testing the research hypothesis, it will be taken as a reference that if the value of $r>0.7$ there is sufficient evidence to accept the hypothesis, otherwise the null hypothesis will be accepted.

\section{Results and Discussion}

The results were analyzed under the following process:

1) First, evaluating the curriculum, in the established dimensions.

2) Second, evaluating the architectural production of the graduates of each curriculum, in the generation of housing under the four parameters of habitability.

3) Third, by checking the research hypothesis, using the simple correlation between the two study variables.

A. From the first data collection instrument, the most notable results are the following:

Regarding what function they performed in their first housing project, (Table 3), it can be seen that in all the plans the largest group is that of graduates who covered the two functions of designing and building their first home, giving a total of $56.2 \%$, while the group that only designed the house was $35.0 \%$ and finally those who only participated in its construction were $8.8 \%$. This indicates that a large group of recent graduates were independent professionals or that they were able to work in an office in which they could do both functions, either due to the size of the company or the capabilities of the graduates.

Table 3. First professional exercise carried out by graduates FADU-UAT.

\begin{tabular}{|c|c|c|c|c|c|c|c|c|}
\hline CURRICULUM & \multicolumn{2}{|c|}{ Design } & \multicolumn{2}{c|}{ Build } & \multicolumn{2}{c|}{ Both } & \multicolumn{2}{c|}{ TOTAL } \\
\hline P-71 & 14 & $24.5 \%$ & 2 & $3.5 \%$ & 20 & $35.2 \%$ & 36 & $63.2 \%$ \\
\hline P-XXI & 2 & $3.5 \%$ & 1 & $1.8 \%$ & 6 & $10.5 \%$ & 9 & $15.8 \%$ \\
\hline P-MIII & 4 & $7.0 \%$ & 2 & $3.5 \%$ & 6 & $10.5 \%$ & 12 & $21.0 \%$ \\
\hline TOTAL & 20 & $35.0 \%$ & 5 & $8.8 \%$ & 32 & $56.2 \%$ & 57 & $100 \%$ \\
\hline
\end{tabular}

Source: Prepared by the researchers (2015). 
Table 4. Type of housing designed / built by graduates of the Study Plans FADU-UAT

\begin{tabular}{|c|c|c|c|c|c|c|c|c|c|c|c|c|}
\hline CURRICULUM & \multicolumn{2}{|c|}{ Social interest } & \multicolumn{2}{|c|}{ Economic } & \multicolumn{2}{|c|}{ Middle interest } & \multicolumn{2}{|c|}{ Residential } & \multicolumn{2}{c|}{$\begin{array}{c}\text { Residential } \\
\text { plus }\end{array}$} & \multicolumn{2}{c|}{ TOTAL } \\
\hline P-71 & 4 & $7.0 \%$ & 0 & $0.0 \%$ & 20 & $35.1 \%$ & 12 & $21.1 \%$ & 0 & $0.0 \%$ & 36 & $63.2 \%$ \\
\hline P-XXI & 0 & $0.0 \%$ & 0 & $0.0 \%$ & 6 & $10.5 \%$ & 2 & $3.5 \%$ & 1 & $1.8 \%$ & 9 & $15.8 \%$ \\
\hline P-MIII & 1 & $1.8 \%$ & 1 & $1.8 \%$ & 8 & $13.9 \%$ & 2 & $3.5 \%$ & 0 & $0.0 \%$ & 12 & $21.0 \%$ \\
\hline TOTAL & 5 & $8.8 \%$ & 1 & $1.8 \%$ & 34 & $59.5 \%$ & 16 & $28.1 \%$ & 1 & $1.8 \%$ & 57 & $100 \%$ \\
\hline
\end{tabular}

Note: The terms: social interest, economic, middle interest, residential and residential plus; is the classification used in Mexico to differentiate the cost of a home

Source: Prepared by the researchers (2015).

Table 5. Weighting scale for Graduate Profile of the FADU-UAT Study Plans

\begin{tabular}{|c|c|c|c|c|}
\hline Deficient & Bad & Regular & Good & Excellent \\
\hline $0-1$ & $1.1-2$ & $2.1-3$ & $3.1-4$ & $4.1-5$ \\
\hline
\end{tabular}

Source: Prepared by the researchers (2015).

Table 6. Averages obtained from the Graduate Profile in each Curriculum FADU-UAT.

\begin{tabular}{|c|c|c|c|c|c|c|c|c|c|c|}
\hline & \multicolumn{10}{|c|}{ AVERAGES } \\
\hline CURRICULUM & 1 & 2 & 3 & 4 & 5 & 6 & 7 & 8 & 9 & 10 \\
\hline P-71 & 4.3 & 4.2 & 4.0 & 3.8 & 3.8 & 4.0 & 3.7 & 3.8 & 4.2 & 4.4 \\
\hline P-XXI & 4.2 & 4.0 & 4.1 & 4.2 & 4.2 & 4.0 & 3.9 & 3.9 & 4.2 & 4.3 \\
\hline P-MIII & 4.0 & 3.8 & 3.5 & 3.4 & 3.7 & 4.0 & 3.6 & 3.4 & 4.2 & 4.3 \\
\hline Averages & 4.16 & 4.00 & 3.87 & 3.80 & 3.90 & 4.00 & 3.73 & 3.70 & 4.20 & 4.33 \\
\hline
\end{tabular}

Source: Prepared by the researchers (2015).

Regarding what type of housing they designed and/or built, in Table 4 it can be seen that in all the plans the largest group is that of graduates whose first professional job was that of an average home, giving a total of $59.5 \%$. While the second type was that of a residential home, giving $28.1 \%$; thirdly the social interest housing with $8.8 \%$, and lastly, the extremes of housing, economic and residential plus with $1.8 \%$ each.

Regarding the graduate profile, 10 items were determined, all on a Likert scale, to measure the perception of the graduates as to how much they had contributed the knowledge acquired during their professional training, to fulfill this profile; establishing for its measurement the scale is shown in table 5 .

The averages obtained from the perception of each of the questions are shown in Table 6.

Each of the ten items, established to measure the graduation profile (Graph 1), are described below, giving the average value obtained in the three study plans. It is worth mentioning that all the results were between the perception of good to excellent:

- The first was aimed at establishing whether they had forged an imaginative, creative and innovative capacity to give aesthetic architectural solutions. The average was 4.16 (excellent).

- The second determined to establish if they had induced the ability to analyze and synthesize architectural phenomena with the specific characteristics of different human groups. The average was 4.00 (good).
The third would allow determining the capacity to respond with architecture to the bioclimatic and contextual conditions of each region. The resulting average was 3.87 (good).

- The fourth would measure the ability to plan, schedule, budget, and manage architectural projects. The average value obtained was 3.80 (good).

- The fifth would establish the ability to define the technology and construction systems appropriate to the architectural solution. The average was 3.90 (good).

- The sixth would evaluate the ability to define the appropriate installation systems for the architectural solution. The average value obtained was 4.00 (good). The seventh would estimate the capacity to build, direct and supervise the execution of architectural or urban works at their different scales. The average result was 3.73 (good).

- The eighth would assess the ability to develop architectural solutions, considering the regulatory and legal requirements to carry out the work. The average was 3.70 (good).

- The ninth would value the ability to discern between what is necessary and what is possible for habitable solutions. Average obtained was 4.20 (excellent)

- $\quad$ Finally, the tenth, with an average of 4.33(excellent), established the ability to expose ideas and transform them into architectural spaces according to the principles of composition and drawing, manual or digital. 


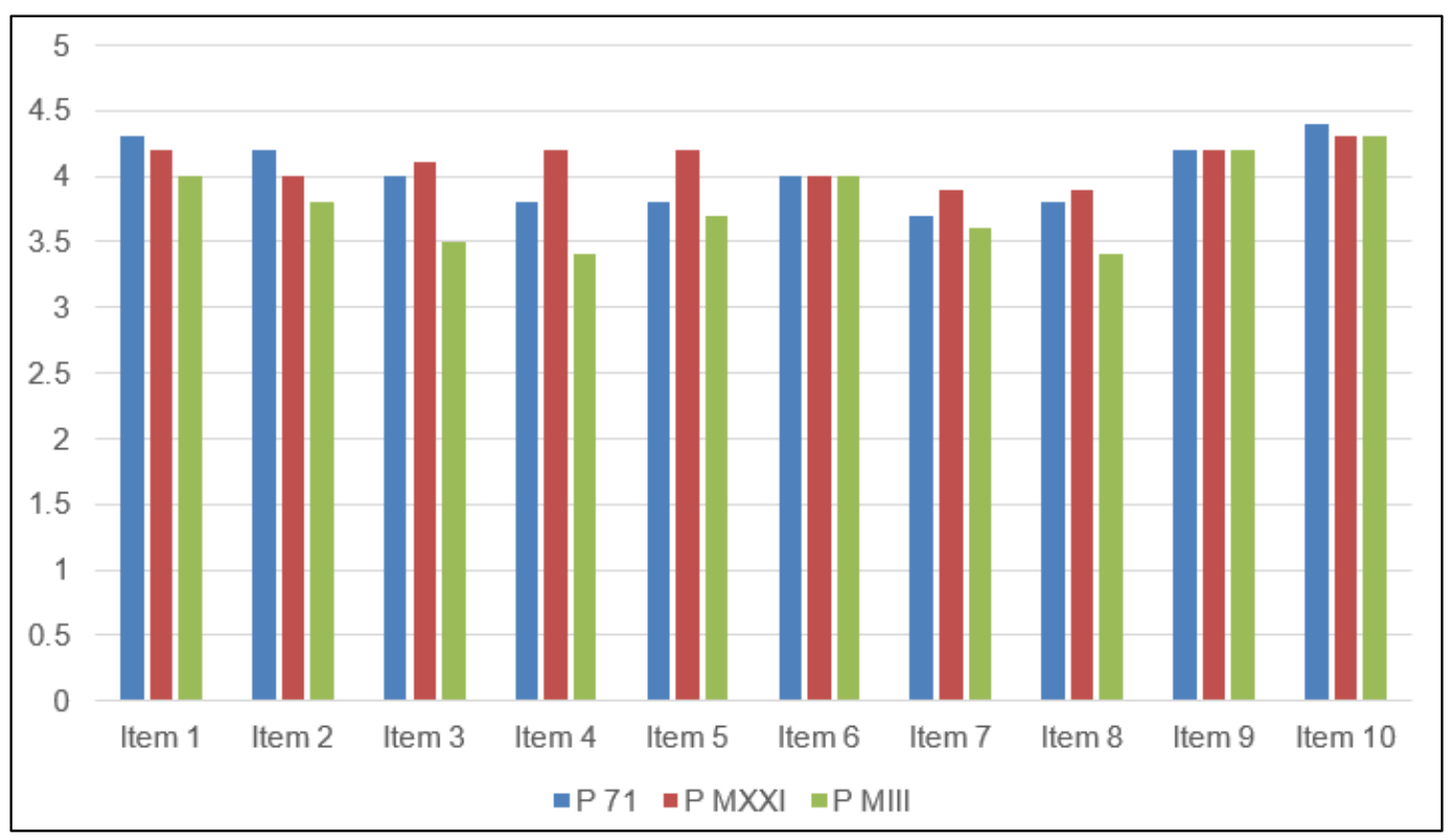

Source: Prepared by the researchers (2015).

Graph 1. Graduate Profile Dimension Averages in each Study Plan FADU-UAT

Once the results of each of the items were obtained, the general average of each study plan was determined, with which the graduates considered with the best contribution to the graduation profile, (Table 7). In general terms, graduates rate it as excellent to good.

Table 7. General averages and outcome of the Exit Profile, in each FADU-UAT Study Plan

\begin{tabular}{|c|c|c|}
\hline Curriculum & General average & Value scale \\
\hline P-71 & 4.01 & Excellent \\
\hline P-MXXI & 4.10 & Excellent \\
\hline P-MIII & 3.79 & Good \\
\hline TOTAL & 3.96 & Good \\
\hline
\end{tabular}

Source: Prepared by the researchers (2015).

Now, if it is analyzed for the three study plans together, it is observed that the item with the highest score was No. 10 , having a general average of 4.33 , which refers to the "Ability to present ideas and to transform them into architectural spaces in accordance with the principles of composition and drawing, manual or digital"; while the item with the lowest score was No. 7, having a general average of 3.73, which refers to "Ability to build, direct and supervise the execution of architectural or urban works on their different scales".

While, in particular, each plan stands out in the following ways (Graph 1):

- For the Plan 71 curriculum, the item with the highest score was No. 10, with a general average of 4.4; while items No. 5 and No. 7 both have the same lowest score with a general average of 3.7. The first refers to the "Capacity to define the technology and construction systems appropriate to the architectural solution," while the second one was already referred to previously.

- For the Mission XXI Curriculum, the item with the highest score was No. 10, having a general average of 4.3; while both items No. 7 and No. 9 share the lowest score with a general average of 3.9. The second item refers to the "Ability to discern between what is necessary and possible for habitable solutions."

- And for the Millennium III Curriculum, the item with the highest score was No. 10, having a general average of 4.3; while both items No. 4 and No. 8 share the lowest score, having a general average of 3.4. The first refers to the "Capacity to plan, program, budget and manage architectural projects"; while the second refers to "Develop architectural solutions, considering the regulatory and legal requirements to carry out the work."

Finally, in relation to the thematic contents, it was feasible to measure the knowledge and skills acquired by the graduates, based on the EGEL-ARQUI instrument, which included 45 professional tasks, in contrast to what was taught in each of the training subjects that were integrated into the different curricula.

For its evaluation, the same three scales established by CENEVAL [16] were used to perform the social validation of the EGEL-ARQUI, in accordance with the following categories and definitions:

- Undergraduate studies: The graduate was asked to indicate whether during their bachelor's degree they studied the concepts, principles or procedures 
necessary to carry out the task. The answer options were YES or NO; Additionally, and for the purposes of this investigation, in case the answer was YES, the graduate was asked to indicate the number of subjects in which the concept, principle or procedure was integrated, either 1, 2, 3 or 4 subjects.

- Importance: Refers to how decisive the proper accomplishment of the task has been in order to perform effectively throughout your professional life. It is a scale with four response options: VI = Very important, $\mathrm{I}=$ Important, $\mathrm{LI}=$ Less important and $\mathrm{NI}$ $=$ Not important at all.

- Frequency: This refers to how often you do the task in your professional work during a year. It is also a scale with four response options: $\mathrm{VF}=$ Very frequent, $\mathrm{F}=$ Frequent, $\mathrm{U}=$ Uncommon and $\mathrm{NF}=$ Not frequent.

In order to carry out the analysis of each of the 45 tasks, the coding for the three established dimensions was established (Table 8), which gave a parameter between a minimum of 2 to a maximum of 13 points.

With this, it was possible to establish the scale (table 9), with which they were categorized by the Study Plan from which each student graduated.
The following results were obtained:

- Of the graduates of Plan 71, they perceive that two professional tasks are Very Relevant, specifically No. 13 and No. 24. Twenty-five is perceived as Relevant, Eighteen are Not Very Relevant. And finally, zero indicated Not at all Relevant.

- Graduates of the Mission XXI Plan highlighted that 15 professional tasks are Very Relevant, with the highest value being No. 24 and subsequently 9, 14, 15, 23, 25, 30 and 31 with the same value. Twenty-seven is perceived as Relevant. Three are Not Very Relevant and zero indicated Not at all Relevant.

- While in the case of graduates of the Millennium III Plan, they perceive that of the 45 professional tasks, 2 is Very Relevant, specifically No. 24 and 25. Twenty-three is Relevant. Twenty is Not Very Relevant. Zero indicated Not at all Relevant.

The results indicated (table 10), show the three professional tasks that obtained the lowest value in the Not at all Relevant and Not Very Relevant categories, as well as the highest value in the other two categories for every study plan. If none is indicated, it should be considered that there were no tasks in that category.

Table 8. Coding of results for professional tasks used by graduates FADU-UAT

\begin{tabular}{|c|c|c|c|c|c|c|c|c|c|c|c|c|c|c|}
\hline \multicolumn{4}{|c|}{ Undergraduate studies } & \multicolumn{4}{c|}{ Importance } & \multicolumn{5}{c|}{ Frequency } & \\
\hline $\mathrm{Y}$ & $\mathrm{N}$ & \multicolumn{3}{|c|}{ Related subject } & NI & LI & I & VI & NF & U & F & VF & Points \\
\hline 1 & 0 & 1 & 2 & 3 & 4 & 1 & 2 & 3 & 4 & 1 & 2 & 3 & 4 & \\
\hline & $\mathrm{x}$ & & & & & $\mathrm{x}$ & & & & $\mathrm{x}$ & & & & 2 \\
\hline $\mathrm{x}$ & & & & & $\mathrm{x}$ & & & & $\mathrm{x}$ & & & & $\mathrm{x}$ & 13 \\
\hline
\end{tabular}

Source: Prepared by the researchers (2015).

Table 9. Scale of results for the professional tasks used by graduates. FADU-UAT

\begin{tabular}{|c|c|c|c|}
\hline \multicolumn{3}{|c|}{ PROFESSIONAL TASKS } \\
\hline Not at all relevant & Not very relevant & Relevant & Very relevant \\
\hline $2-4.9$ & $5-7.9$ & $8-10.9$ & $11-13$ \\
\hline
\end{tabular}

Source: Prepared by the researchers (2015).

Table 10. Best / lowest professional tasks evaluated by graduates FADU-UAT.

\begin{tabular}{|c|c|c|c|c|c|c|c|c|c|c|c|c|}
\hline CURRICULUM & \multicolumn{3}{|c|}{ Not at all relevant } & \multicolumn{3}{|c|}{ Not very relevant } & \multicolumn{3}{c|}{ Relevant } & \multicolumn{3}{c|}{ Very relevant } \\
\hline P-71 & - & - & - & 39 & 44 & 45 & 1 & 9 & 14 & 13 & 24 & - \\
\hline P-XXI & - & - & - & 10 & 39 & 44 & 2 & 16 & 17 & 24 & 9 & 14 \\
\hline P-MIII & - & - & - & 40 & 44 & 45 & 10 & 13 & 1 & 24 & 25 & - \\
\hline
\end{tabular}

Source: Prepared by the researchers (2015). 
A more specific analysis in relation to the three study plans, seeking matches between them, resulted in the determination of which of the 45 professional tasks were selected, although they were not necessarily among the best or worst evaluated:

I. For the Very Relevant category, only one was coincident in the three study plans, specifically No. 24 that mentions "Representing the project through plans".

II. With respect to the Relevant category, seven tasks out of the thirty-six classified were coincident in the three study plans. These were:

- $\quad$ No. 2 "Define concepts that govern the project according to the scope of the architectural genre."

- $\quad$ No. 3 "Analyze representative works of the same genre and their typological characteristics".

- No. 6 "Ground the architectural project by visiting and interviewing potential users."

- $\quad$ No. 8 "Consider sociocultural, political, historical, religious and economic conditions of the different users".

- $\quad$ No. 16 "Develop general zoning and specific areas."

- No. 18 "Propose preliminary solutions of volumetry".

- $\quad \mathrm{N}^{\circ} 33$ "Establish general criteria for gas installations and special criteria for the executive project".

III. In the Not Very Relevant category, there were two coincident tasks in the three study plans that are within the eight classified as such:

- $\quad$ No. 39 "Take the necessary actions to achieve consensus and favorable opinions on the project."

- No. 44 "Implement an architectural services company".

IV. Finally, none was considered as Not at all Relevant.

B. Regarding the second data collection instrument, the main results obtained in relation to architectural production show that graduates:

1) Of the three study plans, mainly used the study of areas to determine the dimensioning of the spaces of the house, leaving as a second option that these were determined by the client.

2) From Plan 71 (61.1\%), from Mission XXI Plan (55.5\%) and Millennium III (58.3\%), respected and integrated the existing trees on the land into the design of the house.

3) From Plan 71 (100.\%), from Plan Misión XXI $(77.8 \%)$ and Millenium III (83.3\%), took into account the orientation to determine the location of the living spaces.

4) From Plan 71 (56\%) and Millenium III (57\%), indicate that the final result regarding the solar effects was satisfactory, while the graduates of Mission XXI Plan (54\%), indicate that it was very satisfactory; (the most used elements to mitigate the sun being eaves, trees and an adequate orientation).

5) Of the three study plans differ in their perception of the dwellings' thermal comfort. While $22 \%$ of graduates consider that the dwellings have a thermal comfort considered cool in summer, $45 \%$ of the graduates consider that the dwellings are in an intermediate thermal temperature between cool and warm.

Weighted each of the 21 items integrated in the four dimensions, the average value was obtained that gave the final result for each of the four factors, on a scale of 1 to 10 (Table 11 and Graph 2).

Table 11. Average by the curriculum of the four factors for habitability, in homes designed and/or built by FADU-UAT graduates

\begin{tabular}{|c|c|c|c|c|}
\hline & \multicolumn{3}{|c|}{ Average } & \multirow{2}{*}{$\begin{array}{c}\text { General } \\
\text { average }\end{array}$} \\
\cline { 2 - 4 } & $\mathbf{P - 7 1}$ & P-MXXI & P-MIII & $\mathbf{8 . 0 3}$ \\
\hline $\begin{array}{c}\text { Physical } \\
\text { dimensions }\end{array}$ & 7.40 & 8.90 & 7.80 & $\mathbf{8 . 0 3}$ \\
\hline $\begin{array}{c}\text { Spatial } \\
\text { Syntax }\end{array}$ & 7.20 & 8.90 & 8.00 & $\mathbf{8 . 3 7}$ \\
\hline $\begin{array}{c}\text { Physical } \\
\text { Comfort }\end{array}$ & 7.30 & 9.00 & 8.80 & 7.87 \\
\hline $\begin{array}{c}\text { Spiritual } \\
\text { Comfort }\end{array}$ & 6.80 & 8.60 & 8.20 & $\mathbf{8 . 2 0}$ \\
\hline $\begin{array}{c}\text { General } \\
\text { average }\end{array}$ & $\mathbf{7 . 1 8}$ & $\mathbf{8 . 8 5}$ & & \\
\hline
\end{tabular}

Source: Prepared by the researchers (2015). 


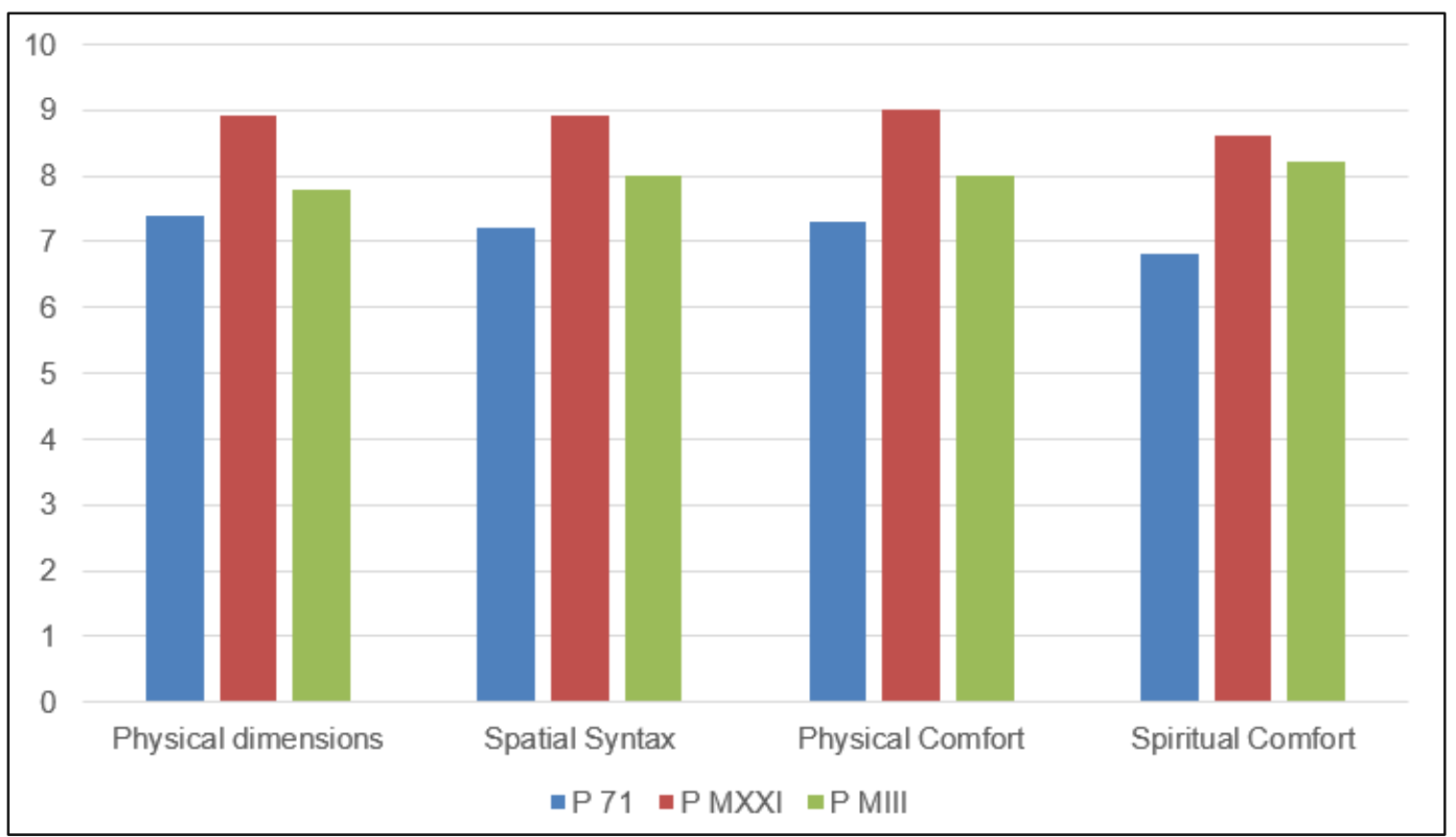

Source: Prepared by the researchers (2015).

Graph 2. Habitability Dimension Averages in each Curriculum FADU-UAT

C. Regarding the verification of the established research hypothesis, it was determined that:

In analyzing each study plan, regarding the interrelation of the two study variables, it was determined that these did not make a difference in the professional production of houses with a habitability approach.

This leads to determine with the evidence found in each of the data collection instruments applied to the graduates involved in the research, that there is insufficient evidence at the alpha significance level equal to 0.05 to accept the research hypothesis, which posed:

$\mathrm{H}_{1}=$ The different study plans for the professional training of the architecture students of the FADU of the UAT: Plan 71, Mission XXI and Millenium III; have marked differences in the professional production of their graduates, evidenced mainly in the area of housing.

Therefore, the null hypothesis had to be accepted.

\section{Conclusions}

Houses constitute more than $70 \%$ of the urban landscape of the cities. It is assumed that the people in charge of building this urban fabric, in which these architectural objects are included, are the architects. These professionals are dedicated to designing and projecting living spaces, with the intention of solving the problems of human habitat. They give consideration to the social, cultural, economic and technological characteristics of the moment, observing that housing is ideal and different in each society and it also depends on the characteristics and personal needs of each individual.

The demand for housing construction in Mexico, according to CONAVI, [7] and CIDOC [8], will increase considerably in the medium term. According to these projections, it is calculated that $75 \%$ of the population will live in cities and metropolitan areas by 2030 .

This will lead to the need for any graduate of architecture to face the impact of having to fill this increased demand for satisfactory living spaces. It happens that only a minimum percentage of professionals in this discipline do so directly. Most, indirectly impact other activities related to home design and construction.

It is noteworthy in the context of most cities in Mexico, that in the urban landscape, houses with poor architectural solutions have been identified and even analyzed by other researchers (Garcia, [19]). Their analysises indicate that the planning of solutions both for the housing unit and for the subdivision do not even comply with what is established by Mexican regulations. This occurs mainly in the design of social interest housing.

The latter has led to the assumption that the architects did not adequately attend to this need and therefore also cast doubt on their training as professionals. However, this research, even being a case study, reflects that the architecture graduates of the FADU-UAT, have been provided with the relevant tools and knowledge for the efficient exercise of their profession, regardless of the study plan from which they have graduated.

Regarding these graduates, when comparing the architectural production of the houses within the southern metropolitan area of Tamaulipas, and measured according 
to the parameters of habitability and knowledge acquired through the thematic contents of the subjects of their academic-professional training, it has been found that this has indeed been a basic premise considered for their design.

This leads to determining that the deficiency is not in vocational training, but in the lack of opportunity that several of the recent graduates have had to be able to apply the theory and practice of what was taught in the classrooms of the university. They have to carry out tasks and functions that are related to architecture but in a phase of the design and/or construction process in which decision-making has already been made. Therefore they can do little to correct the deficiencies that can be detected in relation to the habitability of the houses.

This is due to the fact that the majority of the population and the companies dedicated to construction use graduates of architecture schools indirectly. This is for various reasons, both economic and social and cultural.

Additionally and as mentioned at the beginning of this work, the inadequate controls established in the various norms or regulations that establish the conditions for the generation of quality housing with habitability parameters, specifically developed in production, also have a negative influence on social housing for the medium and low socio economic sector.

This leads to the conclusion that understanding architecture through practice leads to perceiving it in a critical, reflective, and creative way. The architect graduate as an apprentice, in an effort to interpret the basic concepts, is inundated with a sea of questions that are not resolved until he comes into contact with the practice of this discipline, doing architecture leads to experience and experience leads to knowledge.

\section{REFERENCES}

[1] Canales Fernanda (2017) "Territorio + Vivienda Colectiva" En Aguilar K \& Esparza J (Coord) Vivienda Infonavit, Tercera época Volumen 2, Número 1; pp 66-73, Centro de Investigación para el Desarrollo Sostenible del Instituto Nacional del Fondo Nacional de la Vivienda para los trabajadores; México (En red) Disponible en: https://infonavit.janium.net/janium/Documentos/64452.pdf

[2] Cabrera Granillo D \& Guillén Lúgigo M (2018) "La problematica del abandon de la vivienda de interes social en las ciudades globales, una mirada desde sus habitantes" Revista Las ciencias sociales y la agenda nacional, Volumen IX Problemas urbanos y del territorio, Consejo mexicano de ciencias sociales AC pp 313-358 UASLP, México (En red) Disponible en: https://www.comecso.com/ciencias-sociales -agenda-nacional/cs/issue/view/9/9

[3] Bazant Jan (2008) "Expansion and Consolidation urban processes on low income groups periphery zones" Revista Bitacora 13 junio-diciembre 2008, pp 117-132; Universidad
Nacional de Colombia, Bogotá (En red) disponible en: https://revistas.unal.edu.co/index.php/bitacora/article/view/ 18527

[4] Barrios y Ramos García, D.M. (2014). "Fundamentación para la formación de los arquitectos” En D. M. Barrios y Ramos García (Ed.), En Doctorado en Arquitectura con Orientación en Vivienda. FADU, México.

[5] Vitrubio Polión, M.L. (1995) "De Architectura. Los diez libros de arquitectura" (Oliver Domingo, J. L. Trad.) Alianza Editorial, S. A. (Obra original publicada en 15 a C.) Madrid.

[6] Roux-Gutiérrez, R., Espuna-Mujica, A. y García-Izaguirre, V. (2010), "Manual Normativo para el desarrollo de vivienda sustentable de interés social en México", Plaza y Valdés, México.

[7] Comisión Nacional de Vivienda CONAVI (2008) “Criterios e Indicadores para los desarrollos habitacionales sustentables en México" CONAVI, México

[8] Centro de Investigación y documentación de la casa AC; CIDOC (2013) "Estado actual de la vivienda 2013" CIDOC - SHF, México.

[9] Barrios y Ramos García, D. M. (2010) "Marco de Referencia", in Roux Gutiérrez, R., Espuna Mujica, A. y García Izaguirre, V. (Compilers), "Manual Normativo para el desarrollo de vivienda sustentable de interés social en México", México, Plaza y Valdés.

[10] Universidad Autónoma Metropolitana UAM (2012) "Resultados de la encuesta aplicada a egresados de la Licenciatura en arquitectura" División de Ciencias y Artes para el Diseño Unidad Xochimilco- Casa Abierta al tiempo-Sistema de Información de estudiantes egresados y empleadores, UAM, México. (En red) Disponible en: http://www.uam.mx/egresados/estudios/egre2012/rep/xoc/C AD/P85_Arquitectura.pdf

[11] Espuna Mujica, A.; Elías López, P.; Montalvo Tello, S.; Rosas Lusett M. (2010) "Región húmeda, zona del Golfo, Tamaulipas" in Roux Gutiérrez, R., Espuna Mujica, A. y García Izaguirre, V. (Compilers) (2010), "Manual Normativo para el desarrollo de vivienda sustentable de interés social en México", Plaza y Valdés, México.

[12] Filizola Haces, H. (2000) "1 Informe Rectoral” Universidad Autónoma de Tamaulipas, México.

[13] García Izaguirre, V. M. (2010) "Materiales multimedia para la enseñanza de la Geometría Tridimensional. Desarrollo, aplicación y evaluación" Editorial Académica Española, España.

[14] Nadal Cristóbal A. (2005) "El programa universitario como herramienta de evaluación" in unpublished Doctoral Thesis, Department of Pedagogy and Specific Didactics, Universitat De Les Illes Balears, España. (En red) Disponible en: http://www.tdx.cat/bitstream/handle/10803/9392/tanc1de1. pdf? sequence $=1$

[15] Hernández Sampieri, R. Fernández - Collado, C. Baptista Lucio, P. (2006) "Metodología de la investigación" McGraw Hill, México

[16] Centro Nacional de Evaluación para la Educación Superior, A.C CENEVAL (2014), "Encuesta de validación social. Examen General para el Egreso de la Licenciatura en 
Arquitectura" CENEVAL, México

[17] Manzano Patiño, A. Zamora Muñoz, S. (2010) "Sistema de ecuaciones estructurales: una herramienta de investigación. Cuaderno Técnico 4" CENEVAL, México. (En red) Disponible en: http://archivos.ceneval.edu.mx/archivos_por tal/7490/CuadernoTecnico041aed.pdf

[18] Monroy Cazorla, L. Vidal Uribe, R. y SaadeHazin, A. (2010) "Análisis de clases latentes. Una Técnica para detectar heterogeneidad en poblaciones. Cuaderno técnico 2",
CENEVAL, México. (En red) Disponible en: http://archivos.ceneval.edu.mx/archivos_portal/7488/Cuade rnoTecnico021aed.pdf

[19] García Izaguirre VM, Pier Castello ML, Gonzalez Velez J \& Lozano Castro RI (2018) "Viviendas en Tamaulipas: Publicidad vs realidad" en García I, Sánchez M \&Espuna M (Coord) Tçópicos de la Vivienda. Una vision desde la sustentabilidad y la habitabilidad”, pp 15-40 Editorial Colofón, México 